\title{
SIMULASI PEMBUATAN DAN PEMANFAATAN BRIKET PADA LISTRIK KERAKYATAN
}

\author{
Hengki Sikumbang ${ }^{1}$, Rizqia Cahyaningtyas ${ }^{2}$, Indrianto ${ }^{3}$, Abdul Haris $^{4}$ \\ Teknik Informatika STT-PLN Jakarta
}

\begin{abstract}
Abstrak
Sekolah Tinggi Teknik PLN memiliki program penelitian ungggulan dengan tema Listrik Kerakyatan (LK) yang sudah dikaji dan teruji dalam skala kecil dan dapat dikembangkan lebih luas dan lebih mendalam dengan melibatkan berbagai disiplin ilmu terkait. Listrik Kerakyatan adalah inovasi yang dibuat untuk mengelola ketenagalistrikan saat ini dengan menghimpun dan memanfaatkan berbagai teknologi sederhana dan murah yang cocok untuk dikelola oleh masyarakat awam. Bahan bakar utama dari Listrik Kerakyatan ini adalah Sampah perkotaan dan energi yang berasal dari Bio Massa. Tentunya hal ini sangat relevan dengan kondisi Indonesia yang darurat penanggulangan sampah perkotaan serta krisis energi listrik, terutama di daerah pedesaan serta daerah terpencil. Hasil penelitian dan uji coba yang dilakukan oleh STT PLN telah berhasil menanggulangi sampah sebanyak 1 ton per hari (organik dan/atau non organik), dikonversi menjadi briket sampah sebagai bahan bakar pembangkit listrik gas sampah melalui proses gasifikasi. Dalam hal ini, briket sampah ini mampu menjadi energi baru dan mampu menggantikan energi batu bara. Namun untuk dapat diimplementasikan dalam skala nasional, dibutuhkan penelitian lanjutan dengan ruang lingkup yang lebih luas, baik dari sisi teknik dan non teknik. Akhirnya dikembangkanlah inovasi metode "Peuyeumisasi" yang merupakan proses alami menggunakan keramba bambu yang mampu mengkonversi sampah organik dan non- organik menjadi bahan bakar padat. Peuyeumisasi dalam pemrosesan sampah adalah proses pemeraman secara mikrobiologi, bukan kimiawi, yang bertujuan mempecepat terjadinya peluruhan/penguraian (degradasi) sampah padat.
\end{abstract}

Kata Kunci : Listrik Kerakyatan, Briket, Sampah

\section{Latar Belakang}

Listrik Kerakyatan adalah inovasi yang dibuat untuk mengelola ketenagalistrikan saat ini dengan menghimpun dan memanfaatkan berbagai teknologi sederhana dan murah yang cocok untuk dikelola oleh masyarakat awam. Bahan bakar utama dari Listrik Kerakyatan ini adalah Sampah perkotaan dan energi yang berasal dari Bio Massa. Tentunya hal ini sangat relevan dengan kondisi Indonesia yang darurat penanggulangan sampah perkotaan serta krisis energi listrik, terutama di daerah pedesaan serta daerah terpencil. Hasil penelitian dan uji coba yang dilakukan oleh STT PLN telah berhasil menanggulangi sampah sebanyak 1 ton per hari (organik dan/atau non organik), dikonversi menjadi briket sampah sebagai bahan bakar pembangkit listrik gas sampah melalui proses gasifikasi. Terkait briket sampah ini, penelitian yang dilakukan oleh STT PLN di Laboraturium Pengujian Pusat Penelitian dan Pengembangan teknologi Mineral dan Batu Bara (TekMIRA) Kementerian ESDM pada 24 Juni 2015 membuktikan bahwa kadar kalori briket sampah ini berkisar antara 2500 kkal (kalori rendah), 4.445 kkal (kalori sedang), dan $6.730 \mathrm{kkal}$ (kalori tinggi). Dalam hal ini, briket sampah ini mampu menjadi energi baru dan mampu menggantikan energi batu bara. Namun untuk dapat diimplementasikan dalam skala nasional, dibutuhkan penelitian lanjutan dengan ruang lingkup yang lebih luas, baik dari sisi teknik dan non teknik. Persentase Sampah Non Organik jauh lebih besar daripada Sampah Organik. Dalam hal ini, sampah organik telah berhasil diuji dan diimplementasikan oleh banyak pihak. Namun, pada pelaksanaannya, harus terjadi pemilahan antara Sampah Organik dan Sampah Non Organik (yang tidak memiliki nilai ekonomi) baik pada TPS dan TPA. Selain itu, Penumpukan dan pembusukan sampah mengganggu pandangan (estetika) dan menyebabkan terjadnya polusi udara (aroma yang tidak sedap). Bahkan, tumpukan sampah menjadi sarang berbagai binatang yang merupakan vektor penyakit dan sumber berbagai organisma patogen. Sehingga akan terjadi kontaminasi bahan beracun dan berbahaya (B3) ke lingkungan sekltar, sehingga terjadi degradasi kualitas lingkungan hidup. Selanjutnya muncul ide tentang "Bagaimana jika seluruh sampah tidak dipilah (organik dan nonorganik)". Akhirnya dikembangkanlah inovasi metode "Peuyeumisasi" yang merupakan proses alami menggunakan keramba bambu yang mampu mengkonversi sampah organik dan non- organik menjadi bahan bakar padat. Peuyeumisasi dalam pemrosesan sampah adalah proses pemeraman secara mikrobiologi, bukan kimiawi, yang bertujuan mempecepat terjadinya peluruhan/penguraian (degradasi) sampah padat. Metode ilmiah yang mampu memproses sampah organik dan non organik pada box bambu dengan memanfaatkan bakteri anaerob sehingga sampah tersebut dapat menghasilkan suatu produk bricket sampah yang memiliki kadar kalori 2500 - 4000 kkal. Metode ini ditemukan dan dikembangkan oleh Sonny Djatnika Sundadjaya, pakar Listrik Kerakyatan dari Institut Teknologi Bandung angkatan 1974. Dalam metode ini, selain menghasilkan briket, Gas yang dihasilkan adalah gas yang ramah lingkungan. Secara kimiawi, gas sampah adalah $\mathrm{CO} 2+\mathrm{CH} 4$. Untuk itu perlu 
dilakukan briketisasi dan dilakukan gasifikasi sehingga menghasilkan $\mathrm{CO}+\mathrm{H} 2$.

\section{Metodologi Penelitian}

Tahapan penelitian dari Simulasi pembuatan dan pemanfaatan briket pada penelitian ini menggunakan Multimedia Development Life Cycle sebagai berikut :

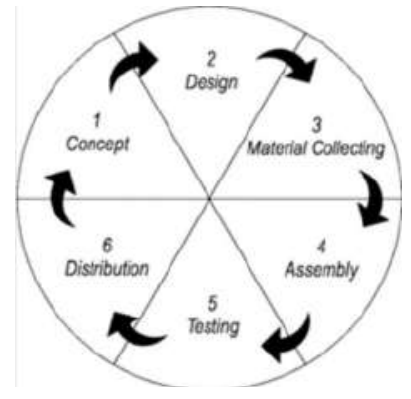

Gambar 1. Metode Penelitian

\section{Concept}

Dalam tahapan ini ada beberapa tahap yang perlu diperhatikan, antara lain:

1. Menentukan tujuan simulasi yaitu untuk mempermudah pembelajaran Sistem pembuatan briket dan pemanfaatan briket agar mahasiswa dan masyarakat umum dapat lebih termotivasi untuk belajar tentang pengolahan sampah.

2. Simulasi ini digunakan untuk media pembelajaran mata kuliah Teknik Animasi dan Animasi Pemodelan oleh dosen dan mahasiswa Sekolah Tinggi Teknik PLN.

3. Deskripsi Simulasi Pembuatan dan pemanfaatan briket berbasis Multimedia ini berjalan dan dioperasikan pada perangkat berbasis Desktop.
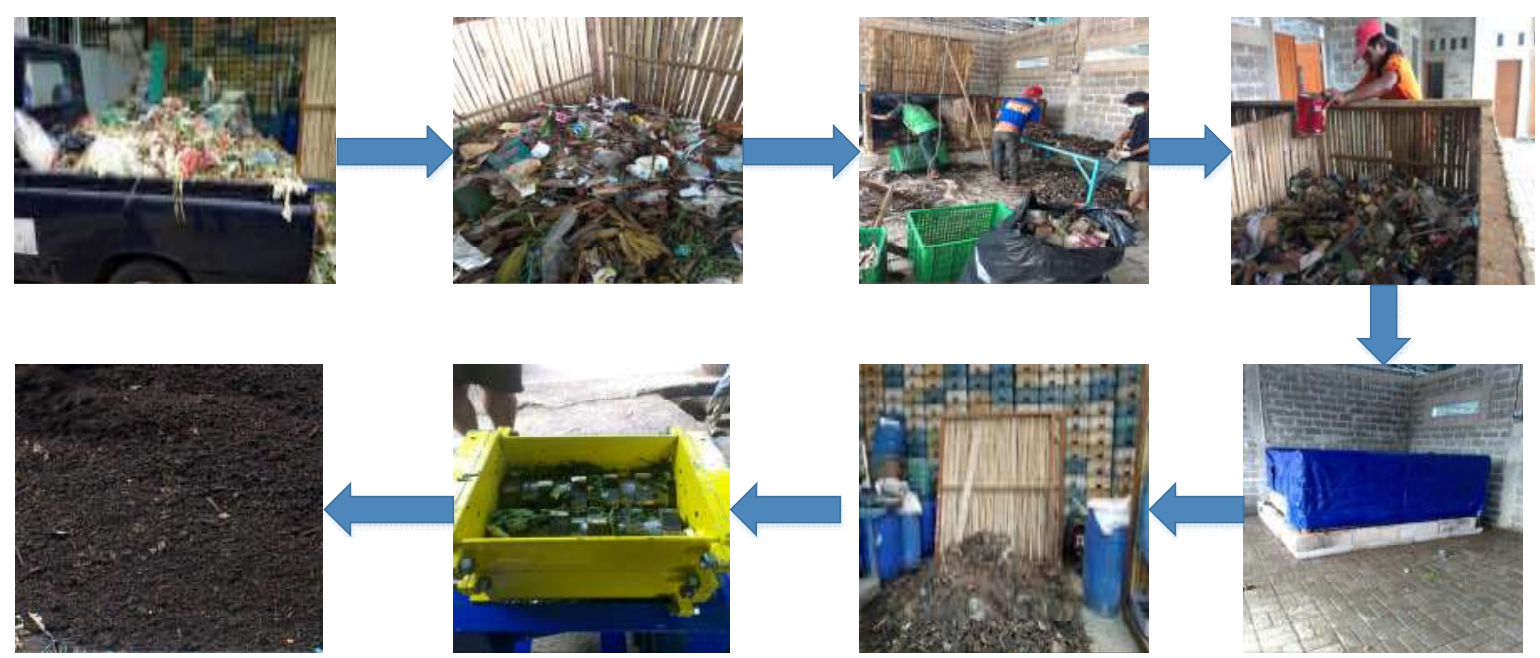

Gambar 2 Tahapan Proses

Diatas adalah kegiatan hasil survey di lokasi Listrik Keraktan Pondok Kopi dimana Sampah yang akan diolah menjadi briket ketika datang ketempat pengolahan sampah akan terlebih dahulu di istrirahatkan pada tempat sampah sementara, setelah itu sampah akan dibawa ke tempat pemilahan sampah. Di tempat pemilahan ini sampah akan dipilah menurut jenis sampahnya yaitu yang dapat dimanfaatkan untuk membuat briket. Berupa sampah organik dan non organik. Sampah organic yang telah dipisah akan dicampurkan oleh lindi yang dihasilkan oleh Permentasi sampah. Setelah itu sampah akan dibiarkan selama 4 hari dengan dijaga suhu dan kelembabanya sehingga bakteri yang dihasilkan akan berkembang dengan baik. Dengan ditutup oleh terpal dan disimpan didalam keranjang sampah yang dibuat dari bambu. Setelah itu sampah yang telah diberi lindi tadi siap untuk dicacah untuk dijasikan bubuk briket. Dari bubuk briket ini selanjutnya akan dicampur dengan tepung sagu agar dapat dicetak menjadi briket sampah.

\section{Design}

Pada tahapan ini dibuat spesifikasi aplikasi secara rinci dalam sebuah perancangan simulasi. Di mana pembuatannya disesuaikan berdasarkan pada Perancangan Diagram Alur (Flowchart). Dalam aplikasi ini terdapat 2 diagram alur (flowchart), yaitu:

1) Flowchart Intro

\section{Material Collecting}

Pada tahapan ini, materi terkait bahan ajar/materi pembelajaran didapatkan dari wawancara kepada operator Listrik Kerakyatan di Pondok Kopi dan operator Listirk Kerakyatan yang berada di gedung LK kampus STT PLN, membaca buku dan mencari sumber-sumber lainnya dari internet. Sedangkan untuk materi terkait Multimedia, penulis mendapatkan materi dari buku referensi, internet dan tanya jawab dengan orang yang lebih ahli. 


\section{Assembly}

Tahap assembly (pembuatan) adalah tahap dimana semua objek atau bahan multimedia dibuat. Pembuatan aplikasi didasarkan pada flowchart. Semua objek atau material dibuat dan digabungkan menjadi satu aplikasi yang utuh. Dalam tahapan ini digunakan software Flash.

\section{Testing}

Tahap ini disebut juga sebagai tahap pengujian alpha (alpha test) dimana pengujian dilakukan oleh pembuat atau lingkungan pembuatnya sendiri. Dalam pengujian aplikasi ini dilakukan pengecekan ketepatan benda berdasarkan marker, karena hanya menggunakan satu buah marker. Pengujian selanjutnya adalah pengujian terhadap ketersediaan benda/obyek 3D. Pengujian selanjutnya dengan menggunakan pengujian kuisioner dengan responden mahasiswa dan dosen STT PLN.

\section{Distribution}

Dalam tahapan ini, aplikasi yang telah selesai di uji dan dinyatakan baik sesuai dengan tujuan pembuatan, akan didistribusikan dengan cara mengunggah ke sebuah toko online Android.

\section{Hasil dan Pembahasan}

Dalam penelitian ini tahap pertama yang dilakukan adalah memahami dan mengenal konsep yang akan dibangun dalam memahami langkah langkah yang akan dilakukan, langkah pertama adalah melakukan identifikasi tahapan dalam pembuatan simulasi aplikasi seperti :

a. Tahapan Pengenalan Listrik Kerakyatan

Pada tahap ini isinya merupakan tahap penjelasan dan pemaparan Listrik Kerakyatan (LK) yang didefinisikan sebagai model penyediaan dan pengembangan energi listrik yang terdiri dari bauran pembangkit sederhana dari energi bersih yang tersedia di sekitar komunitas sehingga dapat dibangun sendiri dilakukan secara bergotong-royong oleh berbagai kelompok masyarakat di tingkat kelurahan di seluruh tanah air. LK ini juga dapat dipandang sebagai gagasan berupa perubahan pola pikir dalam mengelola ketenagalistrikan dengan memanfaatkan teknologi yang sederhana dan murah, dengan bahan bakar utama adalah sampah dan energi yang berasal dari biomassa, untuk dikelola oleh masyarakat. Gagasan LK ini muncul didasari oleh pemikiran bahwa membangun 1 unit pembangkit sebesar $1000 \mathrm{MW}$ sama hasilnya dengan membangun 1000 pembangkit berkapasitas $1 \mathrm{MW}$. Untuk membangun pembangkit 1000 MW diperlukan modal yang besar dan waktu yang lama, sedangkat untuk pembangkit $1 \mathrm{MW}$ tidak memerlukan modal besar dan bisa diselesaikan dalam tempo kurang dari 1 tahun. Berdasarkan definisi Listrik Kerakyatan tersebut, maka kriteria dari LK adalah sebagai berikut (Supriyadi, 2016):

b. Tahapan Pengumpulan Sampah

Pada tahapan ini merupakan tahapan pengumpulan sampah dari masyarakat baik itu sampah yang organik maupun non organik, sampah-sampah yang terkumpul kemudian dipilah sebelum sampah tersebut ditampung dalam bak sampah.

c. Tahapan Pemilahan Sampah

Pada tahapan ini merupakan tahapan pemilahan sampah organik dan sampah non organik, sampah organik akan langsung dimasukan dalam bak sampah untuk diPeuyeumisasi dengan mancampur sampah tersebut dengan cairan Lindih. Sementara sampah non organik akan dipisah dan dibakar didalam tungku Sidaus.

d. Tahapan pengolahan Sampah

Tahapan ini merupakan tahapan bagian dari proses pemilahan sampah organik dan non organik pada sampah non organik akan dibakar dalam tungku Sidaus yang kemudian abunya akan dicampur dengan sampah organik atau juga bisa diproses menjadi batako sampah

e. Tahapan Peuyeumisasi Sampah

Tahapan peuyeumisasi merupakan tahapan pencampuran cairan Lindih dalam bak sampah yang telah dipenuhi dengan sampah pada tahapan ini sampah akan di diamkan dalam 12 hari kemudian sampah tersebut di cek apabila kepadatan sampah meningkat makan akan dimasukan sampah baru dan dicampur kembali dengan cairan lindih. Proses ini akan berulang secara terus menerus sebelum sampah itu cincang dan dimasukan kedalam biogester.

f. Proses pada Tabung Biogester

Pada tahapan ini sampah yang telah di peuyeumisasi kemudian digiling menggunakan mesin penggiling kemudian hasil gilingannya akan dimasukan kedalam Tabung Biogester untuk menghasilkan Gas yang dapat digunakan untuk memasak, Air Lindih yang diperoleh dapat digunakan untuk proses peuyeumisasi selanjutnya dan Ampas yang dihasilkan dapat digunakan untuk pupuk atau sebagai bahan untuk membuat briket.

g. Pengolahan Sampah Non-Organik

Pada proses ini sampah Non-Organik yang telah dikumpulkan kemudian dimasak bersama oli dengan kuali besar dan kompor gas. Setelah itu, campurkan ampas dari biogester ke dalam kuali besar tersebut sehingga menjadi adonan

h. Proses Pembuatan Briket.

Setelah menjadi adonan, adonan tersebut kemudian dibentuk menjadi bola-bola kecil yang dinamakan Briket. Selanjutnya briket dibawa ke tempat Tabung Gas Sipayer untuk diolah

i. Pengolahan Briket.

Briket dimasukkan kedalam Tabung Gas Sipayer. Setelah itu tutup tabung serapat mungkin bila perlu gunakan pasta gigi agar tidak terdapat celah udara untuk masuk dan pasangi lakban pada bagian pinggir tutup tabung agar lebih rapat. Setelah tertutup rapat, lakukan pembakaran briket menggunakan pemantik pada lubang yang telah disediakan. Pembakaran briket akan menghasilkan gas 
dan debu. Kemudian nyalakan pompa air dengan tujuan memisahkan gas dan debu yang akhirnya hanya menghasilkan gas saja.

j. Pengaliran gas menuju genset

Kemudian gas tersebut dialirkan menuju genset untuk mengubahnya menjadi energi listrik yang akan disimpan ke dalam aki.

\section{Rancangan Desain Sistem yang akan dibangun}

Berdasarkan konsep yang akan dibangun dapat dibuat rancangan aplikasi dalam beberapa tahapan untuk tahap pertama akan dibuat desain Storyboard terlebih dahulu sebagai scenario simulasi, dan setelah itu dibuat desain proses simulasi dalam bentuk flowchat. Berikut skenario Storyboard simulasi:

a. Storyboard Simulasi

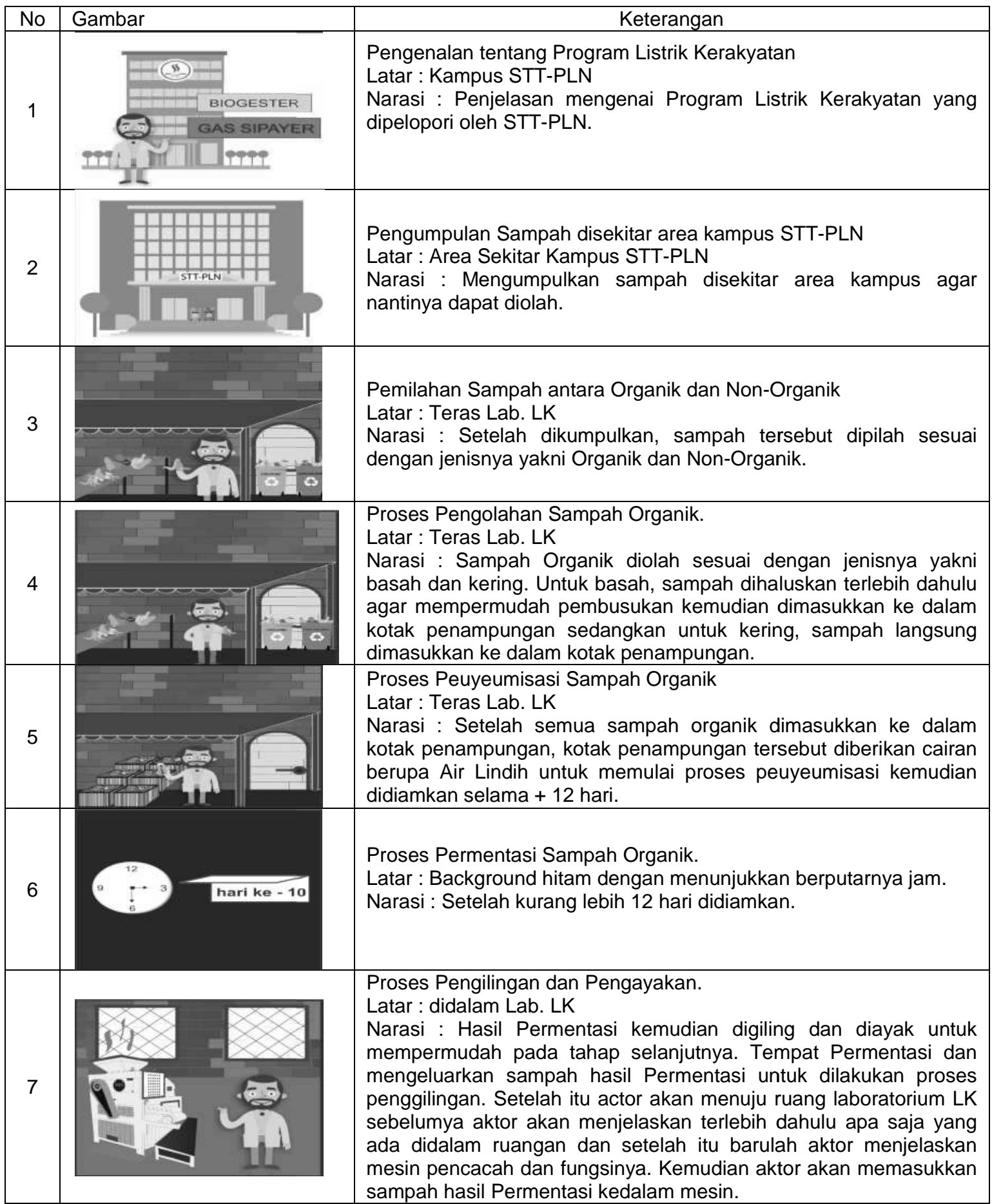




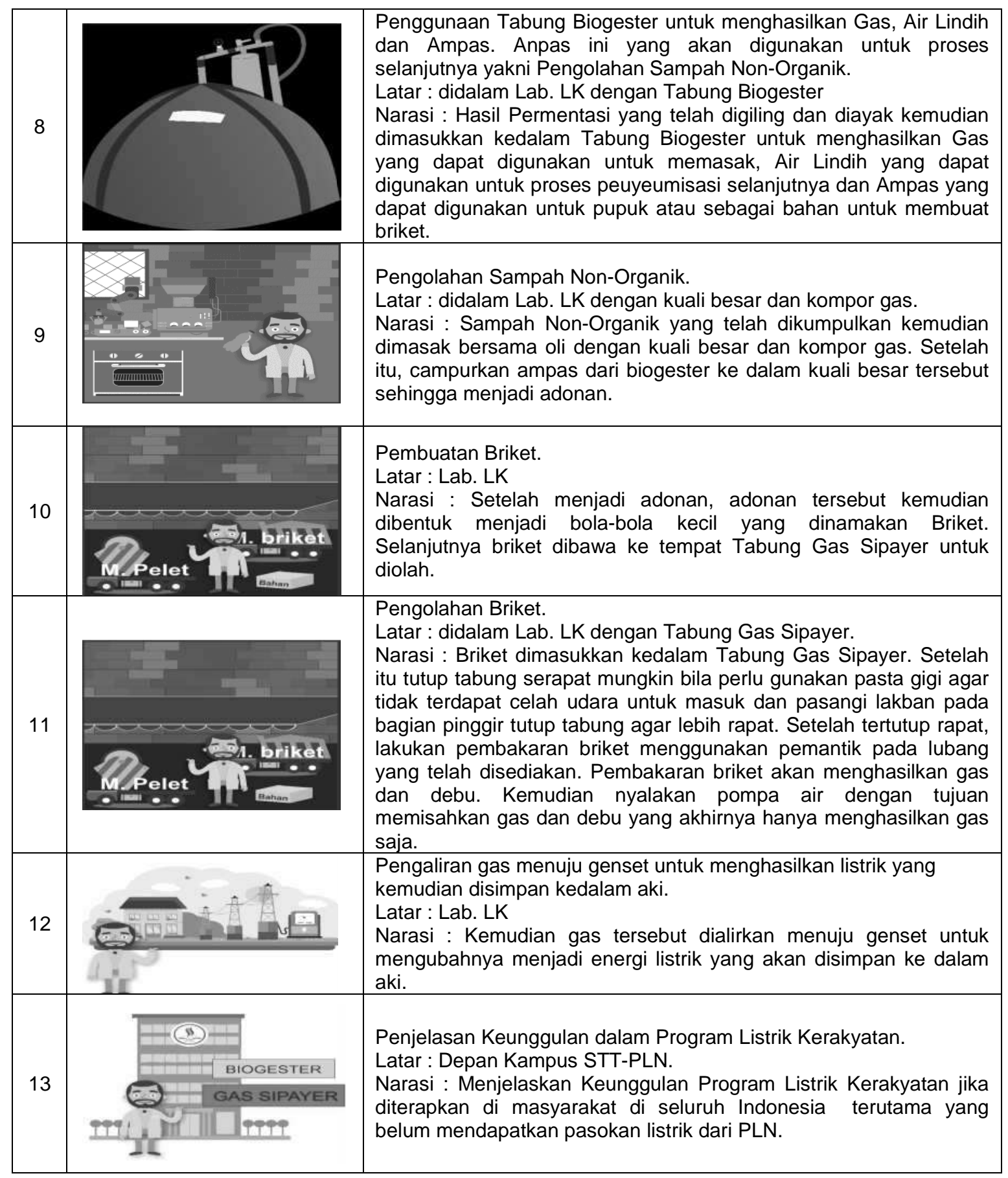

b. Desain Proses simulasi

Pada tahapan desain proses ini merupakan tahapan yang menggambar proses dari video secara garis besar sebelum membuat video simulasi ada beberapa proses video dalam bentuk flowchat sebagai berikut : 


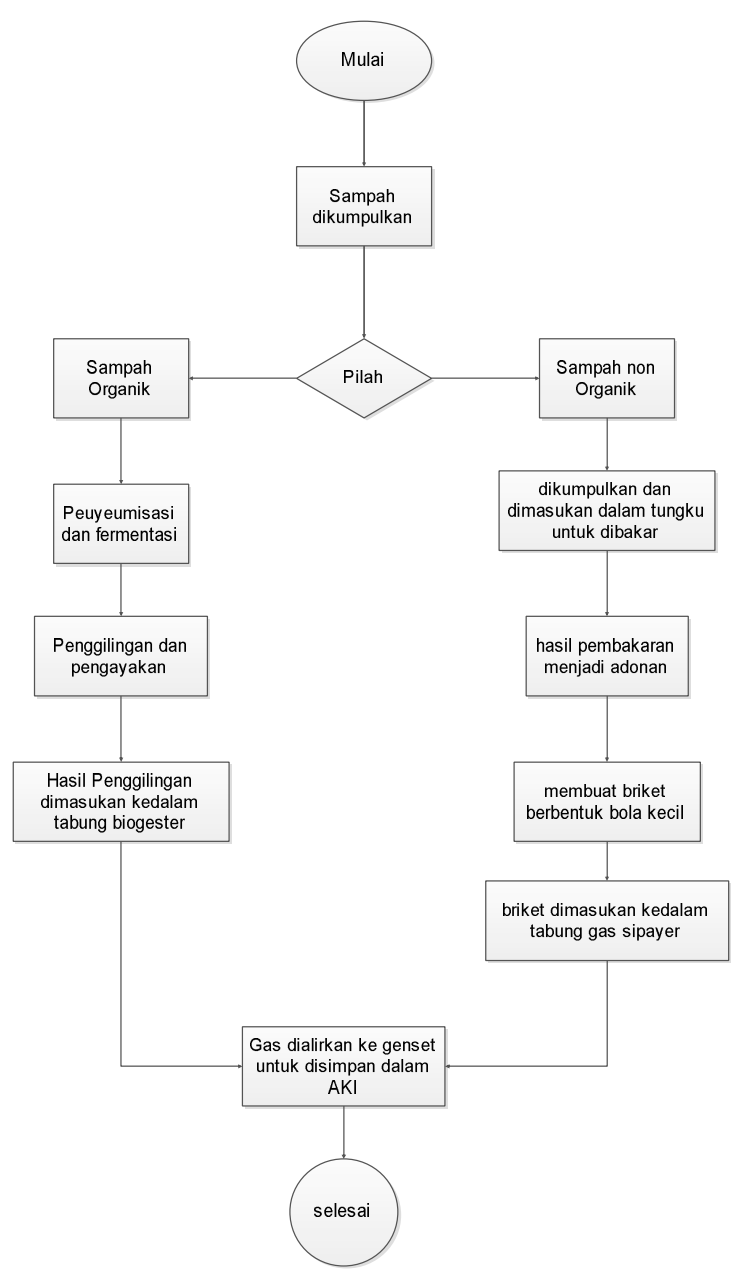

Gambar 3 Flowchat Proses Simulasi

Pada flowchat diatas dapat dilihat setiap langkah-langkah dalam pembuatan video simulasi pembangkit listrik kerakyatan. Mulai dari pengumpulan sampah yang ada disekitar lingkungan warga dampak dari kegiatan ini dapat mengurangi sampah-sampah yang berserakandilingkungan warga, kemudian sampahsampah tersebut dipilah antara sampah organic dan sampah non organic proses ini dilakukan untuk mempermudah proses selanjutnya karena sampah organik dan sampah non organik cara pengolahannya yang berbeda. Kemudian setelah tahapan pemilahan selesai dilakukan maka tahapan berikutnya memproses sesuai dengan kategori sampah. Untuk sampah organik dapat langsung ditampung dalam kemudian di peuyeumisasi dan permentasi serta digiling hasil penggilingan kemudian dimasukan kedalam biogester sampai menjadi eneri yang dialirkan ke genset yang kemudian dialirkan ke AKI sementara sampah non organik ditampung dalam tungku sidaus untuk dilakukan pembakaran dari hasil pembakaran ini yang kemudian dibuat adonan selanjutnya adonan dari adonan tersebut dikeringkan menjadi briket kemudian briket tersebut dimasukan dalam tabung gas sipayer dan kemudian dialirkan kegenset untuk menjadi energi dan disimpan dalam AKI.
Pengumpulan Bahan dalam Pembuatan

Pengumpulan bahan merupakan tahapan yang dilakukan sebelum pembuatan aplikasi simulasi adapun bahan-bahan yang digunakan dalam pembuatan aplikasi ini adalah sebagai berikut :

a. Unity

Unity merupakan aplikasi multimedia yang dapat digunakan pada multiPlatform aplikasi ini umumnya digunakan untuk pengembangan Game, selain itu aplikasi ini juga bisa digunakan untuk membuat video yang berbasis multimedia baik pada platform Mobile Android, Iphone, Blackberry, Windows, Linux, Flash, Webplayer, Bahasa program yang mendukung aplikasi ini adalah C\#, Javascript dan Boo. Aplikasi ini akan digunakan untuk mengimplementasikan dari desain menjadi video multimedia

b. Photoshop

Photoshop adalah software yang digunakan untuk memodifikasi gambar atau foto secara profesional baik meliputi modifikasi obyek yang sederhana maupun yang sulit sekalipun. Photoshop merupakan salah satu software yang berguna untuk mengolah gambar berbasis bitmap yang mempunyai tool dan efek yang lengkap sehingga dapat menghasilkan gambar atau foto yang berkwalitas tinggi (jika ingin lebih jauh mengetahui tentang gambar berbasis bitmap silakan download dokumennya di sini).Kelengkapan fitur yang ada di dalam Photoshop inilah yang akhirnya membuat software ini banyak digunakan oleh desainer grafis profesional. Dan mungkin juga sampai saat ini masih belum ada software desain grafis lain yang bisa menyamai kelengkapan fitur dalam Photoshop.

\section{Proses Pembuatan Simulasi}

Proses pemmbuatan Simulasi yang menghasilkan sebuah video yang difungsi untuk menjelaskan proses-proses pembangkit listrik tenaga sampah (PLTSa). Pada pembuatannya didasarkan pada storyboard dan flowchat proses simulasi, simulasi ini dibuat dengan menggunakan Aplikasi unity 3D aplikasi ini mampu menghasilkan video yang hampir sempurna dan mirip dengan aslinya. Setelah dibuat storyboard kemudian didesain tampilan sesuai dengan yang ada pada storydoard. Berikut hasil pembuatannya :

a. Tampilan utama

Tampilan utama merupakan tampilan pertama yang akan tampil ketika video simulasi dijalankan pada tampilan utama pada bagian ini ada penjelasan dan pengenalan Listrik Kerakyatan. Berikut tampilan hasil pembuatan simulasi : 


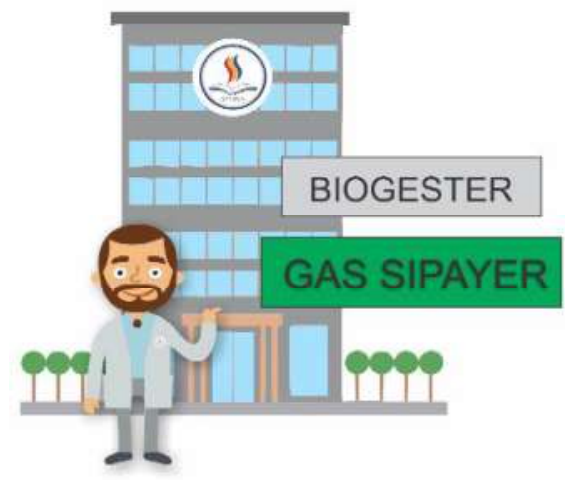

Gambar 4 Tampilan Utama Hasil Pembuatan Simulasi

b. Tampilan Area pengumpulan sampah

Pada tampilan ini adalah tampilan Area yang menjadi sampel dalam pengumpulan sampah dilingkungan Sekolah Tinggi Teknik PLN. Berikut hasil pembuatan simulasi pada video proses pengumpulan sampah :

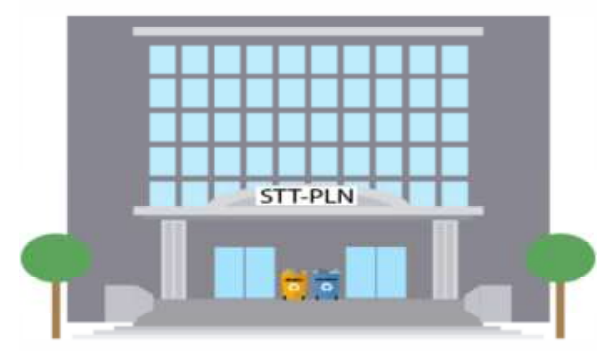

Gambar 5 Area Proses Pengumpulan Sampah

c. Tampilan proses pemilahan sampah

Tampilan berikutnya adalah proses pemilahan sampah, setelah sampah dikumpulkan kemudian dipilah berdasarkan kategori yaitu sampah organik dan sampah non organik. Berikut adalah tampilan simulasi pada video proses pemilahan sampah:

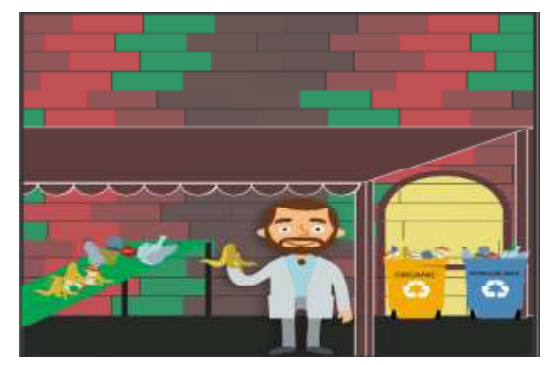

Gambar 6 Proses Pemilahan sampah organik dan non organik

d. Tampilan Proses Peuyeumisasi

Proses peuyeumisasi merupakan proses pencampuran sampah dengan air lindih. Proses ini merupakan proses setelah dilakukan pengumpulan sampah. Berikut adalah tampilan hasil pembuatan simulasi video :

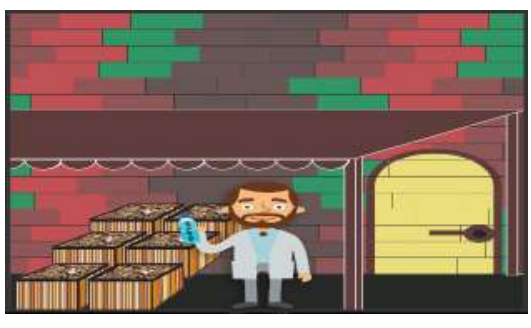

Gambar 7 Proses Peuyeumisasi

e. Tampilan Proses penggilingan

Tampilan berikutnya adalah hasil pembuatan untuk proses penggilingan pada tahapan ini sampah yang telah di peuyeumisasi dan diPermentasi kemudian dimasukan pengilingan. Berikut adalah tampilan hasil pembuatan video simulasi :

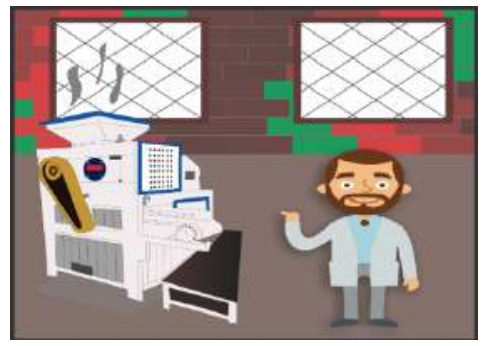

Gambar 8 Tampilan Proses penggilingan

f. Tampilan Proses pada tabung Biogester Pada hasil pembuatan berikutnya merupakan tampilan proses pada tabung biogester proses ini merupakan tahapan yang dilakukan setelah proses peuyeumisasi dan permentasi dan pengilingan setelah sampah di permentasi dan penggilingan maka sampah akan dimasukan kedalam tabung biogester untuk dijadikan gas yang kemudian gas tersebut akan dihubungkan ke genset dan energi nya akan dihubungkan ke AKI. Berikut tampilan hasil pembuatan simulasi pada video :

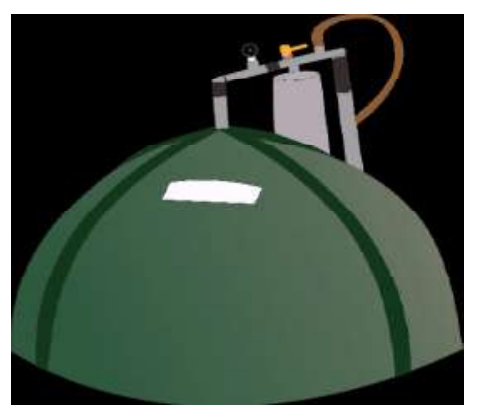

Gambar 9 Proses pada tabung biogeter

g. Tampilan pengolahan Sampah non Organik Tampilan berikutnya merupakan hasil pembuatan pengolahan sampah non organik pada proses ini sampah non organik dikumpulkan kemudian dicampur dengan oli untuk dimasak menggunakan tungku sidaus sampai menjadi abu kemudian abu tersebut dibuat menjadi adonan, kemudian adonan tersebut dibentuk seperti bolah kecil yang 
kemudian dikeringkan menjadi briket selanjutnya briket ini dapat dijadikan bahan bakar. Berikut tampilan hasil pembuatan video simulasi pembuatan briket pengolahan sampah non organik:

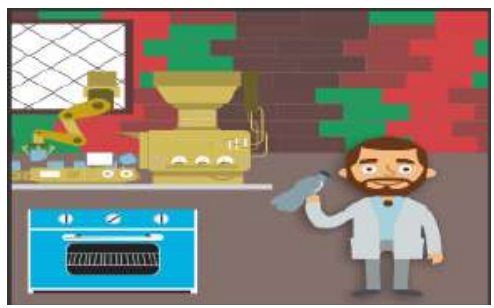

Gambar 10 proses pengolahan sampah non organik

h. Tampilan pembuatan Briket

Tampilan selanjutnya merupakan proses pembuatan briket sampah non organik yang telah dimasak/dibakar maka akan menjadi abu kemudian abu tersebut dibuat adonan selanjutnya adonan tersebut dikeringkan menjadi briket. Berikut tampilan video simulasi hasil pembuatan briket:

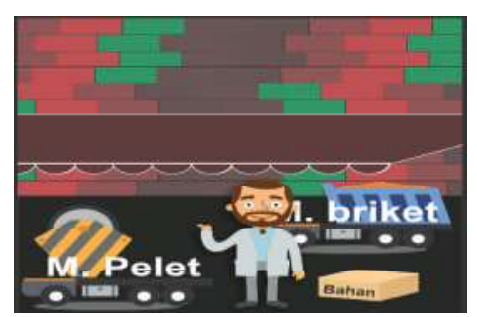

Gambar 11 Proses Pembuatan Briket

i. Tampilan Pengaliran gas menuju genset Hasil pembutan video simulasi berikutnya adalah video simulasi pengaliran gas dari tabung biogester ke genset untuk disimpan didalam AKI. Berikut tampilan hasil pembuatan simulasi dalam video:

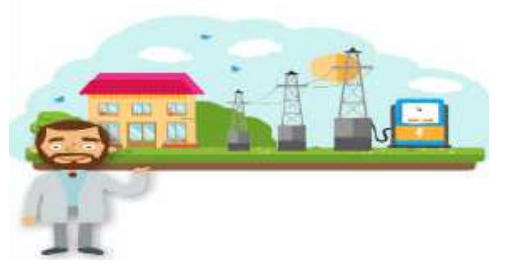

Gambar 11 Tampilan hasil pembuatan pengaliran gas

\section{Proses Pengujian}

Proses pengujian dilakukan dengan memutar video secara utuh, proses pengujian ini disesuaikan dengan bisnis proses pembangkit listrik tenaga sampah (PLTSa). Pengujian masih belum dilakukan karena masih tahapan pengembagan dan pengkajian berikutnya.

\section{Proses Distribusi}

Proses distribusi belum bisa dilakukan karena video simulasi ini masih dalam tahapan pengembangan berikutnya dan perlu dilakukan pengujian terlebih dahulu.

\section{DAFTAR PUSTAKA}

1 Isa I., Lukum H., Arif I.H. 2012. Briket Arang Dan Arang Aktif Dari Limbah Tongkol Jagung. Departemen Pendidikan Kimia;Universitas Negeri Gorontalo, Gorontalo.

2 Jamilatun, Siti, 2008, Sifat-Sifat Penyalaan dan Pembakaran Briket Biomassa,Briket Batubara dan Arang Kayu, Jurnal Rekayasa Proses, Vol2, No.2, 2008, Program Studi Teknik Kimia Universitas Ahmad Dahlan Yogyakarta.

3 Kurniawan, O. dan Marsono., 2008. Superkarbon, Bahan Bakar Alternatif Pengganti Minyak Tanah dan Gas. Penebar Swadaya. Jakarta.

4 Syamsiro, M. dan Harwin Saptoadi, 2007, Pembakaran Briket Biomassa Cangkang Kakao: Pengaruh Temperatur Udara Preheat, Seminar Nasional Teknologi 2007 (SNT 2007), Yogyakarta.

5 http://en.wikipedia.org, dan http://www.bioenergy.org.nz, 2014 